\title{
Examining Teachers' Beliefs on Developing a Digital Pedagogical Framework Based on the SAMR Model for Undergraduate English Language Learning
}

\author{
Iman Al-Khalidi \\ University of Technology \& Applied Sciences \\ Nizwa, Oman
}

Received: January 13, 2021 Accepted: February 11, $2021 \quad$ Published: February 15, 2021

doi:10.5296/ijele.v9i1.18306 URL: https://doi.org/10.5296/ijele.v9i1.18306

\begin{abstract}
Nowadays, technology is considered as an integral rather than a supplementary aspect of high-quality education within the area of TESOL. Accordingly, English language teachers need to be equipped with effective ways to integrate technology into instructional practices not only for enhancing academic outcomes but for confronting the challenges of dealing with the digital native students as well. The purpose of this case study is to examine teachers' beliefs on technology integration into pedagogy based on the measurement of the SAMR (Substitution, Augmentation, Modification, and Redefinition) model. Results of data analysis show teachers' high frequency of technology integration at the Substitution and Augmentation levels compared to the advanced levels of Modification and Redefinition. The study resulted in a recommended SAMR based framework that may help English language teachers move towards effective technology integration that may lead to a more effective learning environment.
\end{abstract}

Keywords: technology integration, SAMR model, digital pedagogy, digital pedagogical framework 


\section{Introduction}

Fundamentally, the role played by teachers for delivering lectures or courses requires to be optimized to achieve the best learning outcomes that are in alignment with the needs and expectations of the "digital native" students who "have grown up surrounded and pampered by technology" (Brown and Lee, 2014, p.237). Today, the majority of teachers are confronting the reality of the net generation who are technologically acquainted and more adapted to using a variety of technology platforms for learning and socially communicating. Moreover, the process of learning is no longer limited to the classroom setting, as previously. Instead, learning has become increasingly dynamic and autonomous as students have the potential to negotiate and construct knowledge on their own via technology communication tools such as mobile devices, social networking sites, software applications, etc. Furthermore, the new technology has been used to help facilitate collaborative discussion, exchange of opinions, and critical thinking (Huang et al., 2012). Undeniably, if these factors are not taken into consideration, teachers and institutions will not be able to confront the unpleasant challenges and impacts on the process of teaching and learning. Probably, the impacts will be stronger on teachers as they are in the frontline of confrontation with the net generations' styles and preferences.

Within the field of TESOL, in addition to the characteristics of the net generation and the digital technology innovation, language learning itself has become highly demanding as it requires learners to have frequent practices to achieve language proficiency (Canagaragah, 2005; Littlewood, 2011). Thus, it has been increasingly important, as several previous studies indicated that teachers must be able to integrate digital technology into their teaching practices to achieve effective learning (Brown and Lee, 2014; Prensky, 2005; Wang and Smith, 2013; Jamieson-Procter et al., 2013; Nakayima, 2011; Cassim \& Obono, 2011). However, the idea of integration is not sufficient unless it is guided by effective, adequate, and systematic methods and tools supported by theories and approaches. This means that teachers are required to develop sufficient competency in technology education to upgrade their teaching to the current era. In other words, they are required to deliver courses and lectures that enable students to engage in the synthesis and evaluation levels of learning that are more advanced than the lower cognitive levels of remembering and comprehension of Bloom's Taxonomy (Krathwohl, 2002).

Research on digital pedagogy repeatedly focuses on the role of technology in engaging and motivating students inside and outside the class. There are numerous studies that have been conducted to confirm that technology contributes to active student engagement. However, there is a lack of research showing the mechanism of how to integrate digital technology across all levels of delivering a lecture or lesson. Also, in spite of all teachers' efforts in enhancing their technology skills, they are still struggling with not reaching the high level of technology integration. This study aims to fill in this gap in the literature by providing insights on how to integrate digital technology into teaching practices. To resolve the gap in the research, the author has sought to investigate through the literature a systematic way that helps TESOL teachers integrate digital technology into their classrooms. 


\section{MInstitute Machink $_{\text {Insthe }}$}

The purpose of this study is to review the literature on technology integration with the main focus on the SAMR model that has been designed by Dr. Ruben Puentedura (2009) to be used as a systematic way of measuring the levels of technology integration by teachers or trainers. The primary purpose of this review is to contribute to the knowledge of literature through designing a contextually tailored model of technology integration shaped and guided by a mixture of theoretical as well as practical views. Hopefully, the model will be of value for teachers' for purposes of enhancing their instructional practices and professional development as well.

This study is guided by the following questions:

Q.1 What are teachers' beliefs on technology integration using the SAMR model in the TESOL classroom?

Q.2 To what extent do TESOL teachers integrate digital technology in the classroom based on the SAMR model?

\section{Literature Review}

The process of technology integration is defined as the process of using technology and digital tools effectively and efficiently in the general content areas to help learners apply technology skills in a meaningful way. Moreover, technology integration means determining which electronic tools and which methods for implementing them are the most appropriate (Koehler and Mishra, 2009). According to Blewett et al. (2009) the process of integration doesn't basically mean replacing technology with the teacher, but rather it means designing materials and activities using digital tools, platforms, webs, etc. in a way that conforms itself to the students. Another view of technology integration is provided by Koehler and Mishra (2009), who consider technology integration as the process of a combination of three basic components: components of teachers' knowledge: content, pedagogy, and technology. They are represented as three bodies of knowledge, PCK (pedagogical content knowledge), TCK (technological content knowledge), TPK (technological pedagogical knowledge), and TPACK (technology, pedagogy, and content knowledge).

In addition to theoretical perspectives, the literature in this area has presented several models that are concerned with technology and pedagogy such as SAMR (Puentendura, 2009), RAT (Huges, Thimas, \& Scharber, 2006), TRIPLE E (Kolb, 2011), and recently Bloom's Taxonomy integrated with technology, as well as others. The literature also shows several studies which suggest that teachers are required to connect their technological, pedagogical, and content knowledge to develop their effective technology integration knowledge, skills, and attitudes (e.g. Howlett et al., 2019; Alivi, 2019; Mouza et al., 2017; Shu-Yuan Fan, 2016; Abdullah, 2014; Yang \& Walker, 2015).

Other researchers (e.g., Tondeur, 2018; Foulger, et.al., 2017; Barton and Haydn, 2006) have sought to examine the potential of enhancing teachers' competencies for technology integration in education. In their Technological Pedagogical Content Knowledge (TPACK) 
framework, Koehler and Mishra (2009) argue that if teachers and educators endeavor to integrate technology in their teaching, they must be competent in these three types of knowledge, and more importantly, they must be able to integrate all three forms of knowledge in their practice.

Some of the previous studies focused on specific models concerned with technology integration. In the area of TESOL, for example, Kristina et.al. (2019) conducted a mixed method study that aimed at developing a service learning experience project based on SAMR model. The Survey results highlighted the need for preservice teachers to gain experience using various technological hardware in educational settings. A similar study was conducted by Justsinta (2019) to review the TPACK and SAMR models to provide insights for language teachers who are interested in the strategy of technology integration. The study also showed the differences between teachers and students' levels of technology competence according to SAMR model measurements. Similarly, several authors (such as Abdullah, 2014; Pfaffe, 2017; Budiman et al., 2018; Yang \& Walker) also focused on employing SAMR model to develop mobile learning for teaching English at the undergraduate levels.

Other studies had different emphases on the importance of technology integration. For example, Fabian and MacLean (2014) employed the SAMR model as a measuring tool to determine the technology integration level during the time of teaching activities. Other authors such as Park (2014) conducted a study to measure the integration between a professional learning network and technology integration through the SAMR model.

\subsection{The SAMR Model in English Language Learning}

The SAMR model was developed by Dr. Ruben Puentedura (2009) to describe how one should use or integrate technology in a learning environment. It is a model or framework composed of four levels: Substitution, Augmentation, Modification, and Redefinition. According to Puentedura, the purpose of the model is to help teachers and educators to design and develop technology-based learning to transform and improve the learning experience for students. Kristina et al. (2019) view the SAMR model as a reflective tool that assists teachers to self reflect and modify their teaching practice using instructional technology. Other authors (such as Ledford, 2016; Chou et al., 2012) think of the SAMR model as a necessary document for a teacher's professional development.

In the area of TESOL, technology integration is highly emphasized, which is due to the fact that language learning requires learners to have more practices to achieve language proficiency. Technology integration to language curriculum provides learners with a variety of opportunities to enhance their interaction, communication, and engagement in tasks and activities (Budiman et al., 2018; Saran \& Seferoglu, 2012; Wang, 2006).

The study's focus is to seek a systematic way of transforming technology into teaching practices that help teachers deal with the needs and preferences of the net generation students. For this purpose, the SAMR model has been picked up because it emphasizes integrating technology across all of the stages of designing an activity or task and allow for technology interaction and increased student engagement. Figure 1 shows the four stages of the SAMR 


\section{Macrothink}

model, along with a brief description of each level.

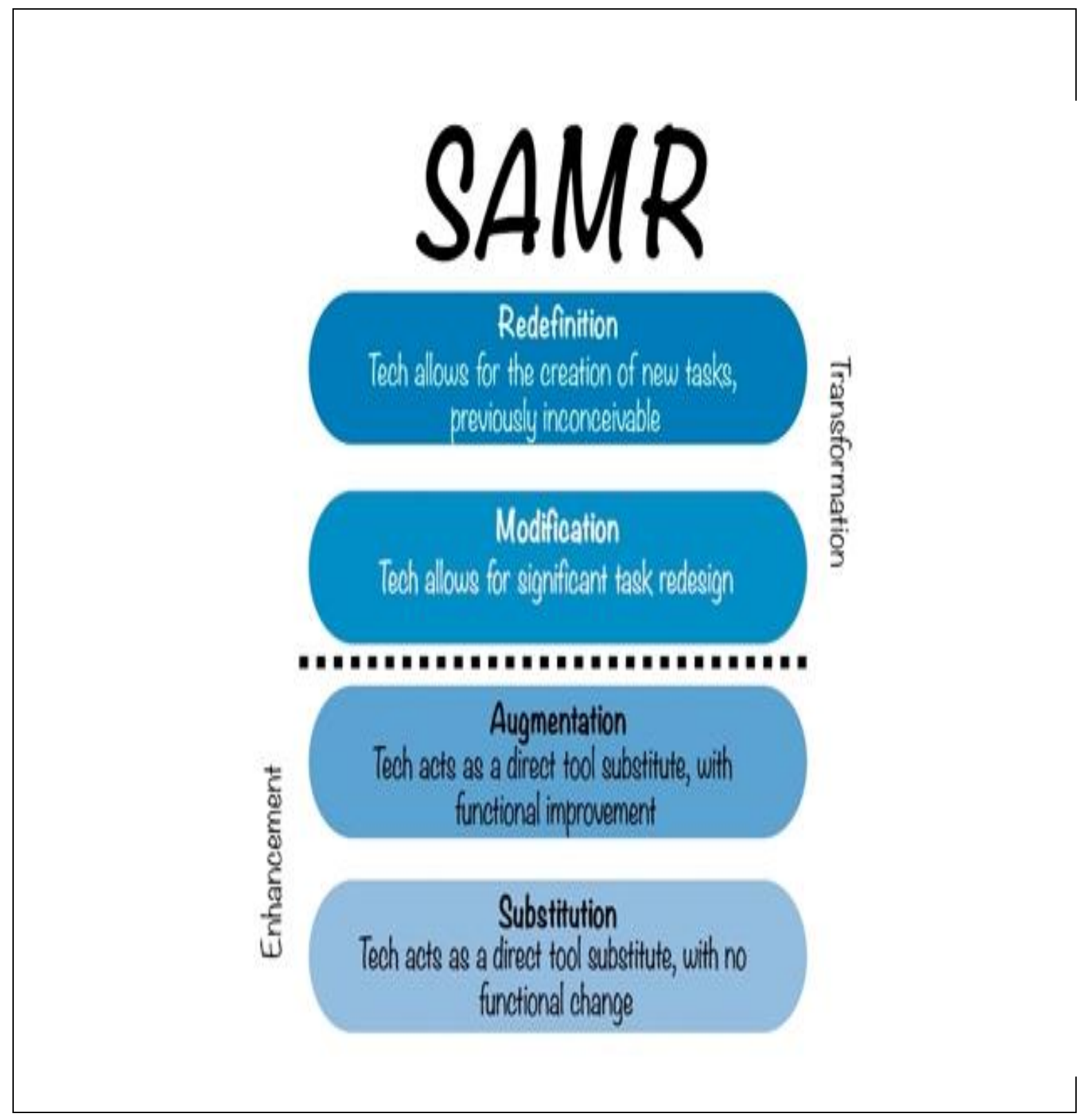

Figure 1. SAMR model of technology integration (Puentedura, 2009)

Substitution- Substitution means "tech acts as a direct tool substitute, with no functional change" (Puentedura, 2009). It is the first level of the SAMR model. In practice, substitution refers to replacing manual tools with digital ones. For example, whiteboards or printout materials are substituted with smartboards, overhead projectors, or laptops as digital delivery tools (Alivi, 2019).

Augmentation- The augmentation process is the second level of the SAMR model where "Tech acts as a tool substitute, with functional improvement" (Puentedura, 2009). It is 
similar to the substitution level, yet it provides students with some functional improvement. The example is when students are asked to write an essay using Microsoft word with a thesaurus or apply google translate to find the words' synonym or antonym or Grammarly to check spelling and grammatical mistakes. In this writing process, students do not only use hardware and software devices (i.e., laptop, Ms. Words) for writing, but they also use other information communication technology functions (i.e., thesaurus, Grammarly), allowing them to learn more knowledge in the process (Alivi, 2019).

Modification-This is the third level of the SAMR model referring to "tech allows for significant task redesign" (Puentedura, 2009). Unlike the first levels that focus on task enhancement, the modification level focuses on task transformation requiring a higher level of thinking skills. For example, students are given a task to write collaboratively using Google Doc., and then they give peer feedback online in the Google Doc. platform. In this activity, Google Doc. does not only act as a digital platform to write, but it is modified as a collaborative platform in an online environment. The students can evaluate (i.e., give feedback) their writing to each other online. The other example, students make a poster presentation using Canva (a graphic design tool website) for writing activities. In the poster making the process, students are challenged their activity to write in a concise yet comprehensive manner, as well as making the poster as attractive as possible by providing relevant images to help readers easily comprehend information in the poster. In this process, the students learning task is not only writing some ideas, but it is modified by giving other learning tasks (e.g., summarizing, researching for related images).

Redefinition- It is the highest level of technology integration referring to "tech allows for the creation of new tasks, previously inconceivable" (Puentedura, 2009). This level requires students to work on creative tasks "such as recording videos to submit as homework and then posting them on social media to ask for feedback from the audience" (Nakapan, 2018 , p.812). In a review study on the SAMR model, Aliva (2020, p. 7) provided an example on integrating technology in the speaking skills at the redefinition level. The example involves asking students to "make a video and upload it to Youtube so that they can reach worldwide viewers; or the teacher provides video conferences with native English speakers so that students can get tangible speaking practices". The same author provided another activity which involves using social media such as the Facebook for writing skills whereby students are required to post their views on the Facebook while other students give responses or comments concerning the post (for more examples see Abdullah, 2014; Budiman, et.al., 2018).

\subsection{The SAMR Model and Bloom's Taxonomy}

Bloom's Taxonomy was first created by Benjamin Bloom (1956) to "promote higher forms of thinking in education, such as analysing and evaluation rather than remembering facts" (cited by Nakapan, 2016, p.812). In the context of technology education, Bloom's Taxonomy has been used as the foundation or the educational stance that upon which the models of technology are built. For example, Carrington (2013) developed what is called "Wheel Pedagogy" that may look complex, but it is a useful tool for incorporating online and digital 
tools and apps when developing a lesson plan. Figure 2 adapted from Andrew Churches (2008) shows the incorporation of numerous digital and online tools with different levels of learning.

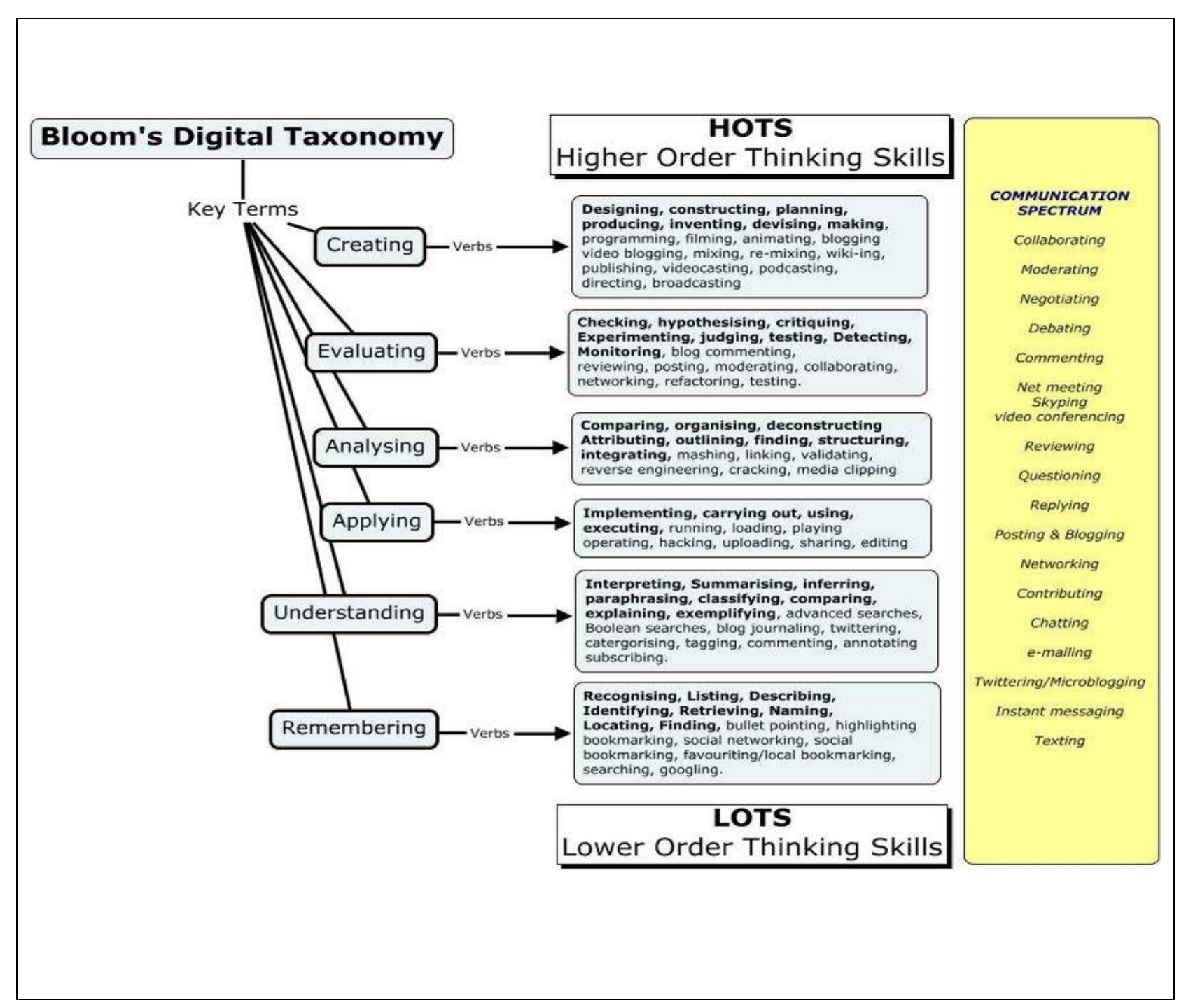

Figure 2.Mind Map of Bloom's Taxonomy Digital. Adapted from Churches (2008)

In relation to the SAMR model, there is an obvious correlation between Bloom's Taxonomy and the SAMR model as both start from the basic level of remembering proceeding to the higher level of analysis and critical thinking (Nakapan, 2016). Both models aim to equip students with the basic knowledge to achieve the highest level of learning. The Substitution and Augmentation levels in the SAMR model are coupled with the Remember, Understand, and Apply levels in Bloom's Taxonomy. The upper levels, Modification, and Redefinition are on the same level as Analyse, Evaluate, and Create (Hilton, 2016).

The SAMR model is more effective when coupled with Bloom's Taxonomy because this 
combination provides a picture of how technology integration according to levels of cognitive and transformative learning. Figure 2 below illustrates the correlation between the SAMR model and Bloom's Taxonomy.

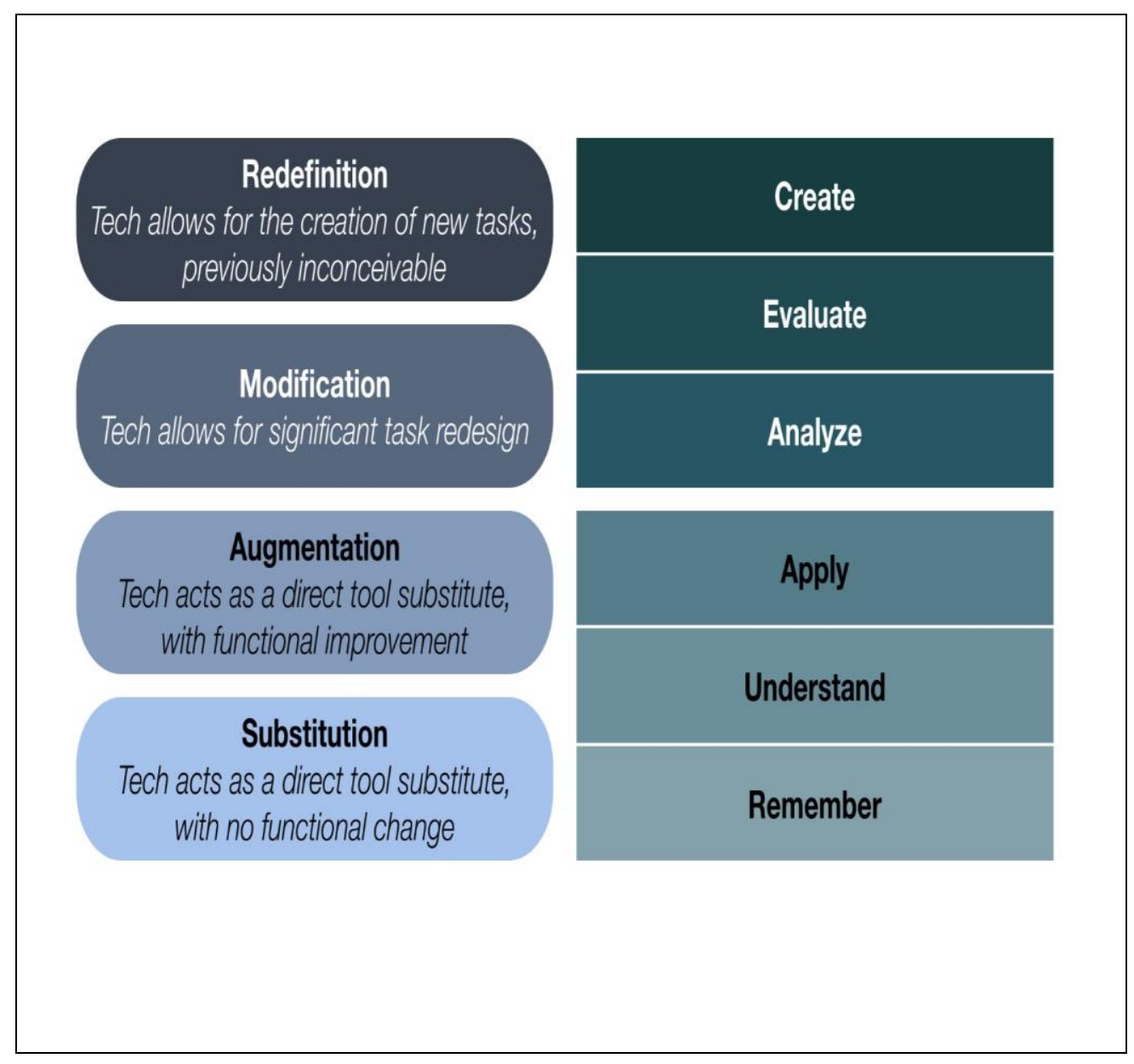

Figure 3. SAMR \& Bloom's Framework

\section{Research Design}

The aim of this research is to explore teachers' beliefs and practices regarding the idea of technology integration in their teaching as well as the extent to which they integrate digital technology in the classroom. Accordingly, the research employed a case study as a strategy that is in conjunction with the interpretivism paradigm underpinning this qualitative study. More specifically, the case study has been selected for the purpose of providing rich insights and developing multiple interpretations from a group of three teachers who are concerned with TESOL (Yin, 2009; Chapelle and Duff, 2003; Devers and Frankil, 2000; Esteberg, 2002). This research was conducted at a community College in Toronto in 2020.

With regard to collecting data for the second question "To what extent do TESOL teachers integrate technology into the classroom?" the SAMR model by Puentedura (2009) has been employed as a data collecting instrument. It has also been used as a data analysis tool as it shows how technology is integrated and at what level (substitution, augmentation, 
modification, and redefinition). According to Puentedura (2009), the SAMR model is intended to be a tool through which one may describe and categorize teachers' uses of classroom technology.

\subsection{Method of Data Collection and Analysis}

The data collection method involved several reflection reports provided by six teachers who were selected purposefully for this case study. The participant teachers were asked to provide reflection reports in a narrative format showing their views and beliefs regarding the process of technology integration in teaching. The reflection reports served as the data for the two research questions. To collect data from the participants, the author first contacted the participants via emails to explain the purpose of the study, the statement of the problem, and the significance of the study.

The author then sent an attachment document including the two research questions along with a few open-ended questions that have been prepared as prompt questions as Dornyei (2011) points out to collect rich and in-depth information from the participants. Table 1 below serves as guiding document for collecting data qualitatively from the teachers.

\subsection{The Analytical Process}

The analytical process involved using Miles and Huberman's model (1994) that is composed of three stages: "data reduction," "data display," and "conclusion drawing/verification." In the data reduction stage, the data were first categorized in terms of the two research questions. Under each category, several themes and keywords emerged, describing the teachers' beliefs on technology integration and the level of their integration based on the SAMR model. The themes were also relating to the research questions and the theoretical analysis of the literature views and the SAMR model.

According to the second stage of data display, the emerging themes were grouped, defined, and displayed. The third stage involves coding the data. In this study, the process of coding begins with reviewing the transcribed data word by word and line by line within each particular answer of each interview to decide which segment that implies important information to include and which segment that is irrelevant to pull out. After reviewing and reflecting on the transcribed data, codes or labels were assigned below or beside each word or segment to describe the aspects of the content. A grounded theory (Strauss \& Corbin, 1998) analysis was the method that attempted to uncover the meaning inductively implied by the teachers.

\subsection{Results and Discussion}

This section presents the findings emerging from the teachers' self-reported reflections. The findings are organized into two sections according to the two research questions (for details about the questions of the study, see Table 1). 


\section{Macrothink}

Table 1. Guided Questions

\begin{tabular}{|l|l|}
\hline Research Questions & Guided questions \\
\hline $\begin{array}{l}\text { Q.1 What are teachers' } \\
\text { beliefs on technology } \\
\text { integration using the SAMR } \\
\text { model? }\end{array}$ & $\begin{array}{l}\text { 1. What do you think of technology integration? } \\
\text { 2. How do you integrate technology into classroom? } \\
\text { 3. Do you follow a specific model for integrating } \\
\text { technology in your teaching? } \\
\text { 4. Do you use the SAMR model for evaluating } \\
\text { activities? If yes how? }\end{array}$ \\
\hline $\begin{array}{l}\text { Q.2 That do you think of using SAMR model as a } \\
\text { mFL/EAP teachers integrate } \\
\text { technology in the classroom } \\
\text { based on SAMR model? }\end{array}$ & $\begin{array}{l}\text { 1. At what level of the SAMR model or Bloom's Taxonomy } \\
\text { 2. Which components of the course design do you mostly } \\
\text { need to integrate technology? }\end{array}$ \\
\hline
\end{tabular}

\section{Finding 1: Teachers' Beliefs on Technology Integration Using SAMR Model}

In response to Research Question 1: What are teachers' beliefs on technology integration using the SAMR model? The results of data analysis revealed that the participant teachers are in favor of integrating technology into their teaching, and they believe that it is beneficial for both the teacher and students. They all reported that technology integration positively impacts student engagement, motivation, creativity, and the most important of all is achieving learning outcomes. Below are two excerpts that are typical examples picked up from the data showing how the participants describe their beliefs regarding this matter.

Excerpt (1)

I believe that integrating technology into the classroom has become a crucial aspect in modern education... Nowadays, technology and pedagogy must work hand in hand not only to support students' learning but also to develop the quality of teaching. I think that technology helps me create a more dynamic, effective, and relaxing atmosphere for learning.

Excerpt (2)

Integrating technology into the classroom is very important as it contributes 
to improving the quality of teaching and learning. In my view, the implementation of technology is a good way to get students engaged in working on tasks and activities and get them involved with critical thinking and problem-solving activities as well. Technology also helps students to be more creative in working things out.

When they were asked about what they think of using the SAMR model as a monitoring tool of their technology integration, they all showed their positive beliefs on this model, although they are not quite familiar with the details or levels of the model. The findings reveal three key words the teachers used for describing the SAMR model, such as 'rubric, modeling, and systematic tool.' For example, one participant said, "I think it would be a good idea if we follow a systematic model or tool to monitor our use of technology." The other participant reported that "We need to model the process of integration as I feel like we do it in a disordered way." The third participant, on the other hand, used another keyword that is "rubric," to describe her belief in using the SAMR model. She believes that the SAMR model can be used as a rubric to follow when checking or monitoring their technology integration.

The finding of teachers' beliefs in the power of technology integration into the classroom goes in line with the theoretical perspectives that emphasize the role of technology integration in the classroom. Experts in the area of English language teaching (such as Brown and Lee, 2014; Chapelle, 2013) are in favor of technology integration, drawing their views on the rationale that technology integration contributes to increasing students' engagement, interaction, and motivation that are viewed as the basic principles of student-centered learning.

Furthermore, teachers' beliefs in the idea of modeling technology with practices and activities in English language teaching reflects teachers' awareness of the role of technology in raising the quality of education and their professional development (Koehler, Mishra\& Yahya, 2007); Lawless \& Pellegrino, 2007; Matherson, Wilson, \& Wright, 2014). However, teachers' awareness of technology integration is not sufficient if teachers don't possess technology knowledge or competency and know-how to integrate it into their teaching (Brown and Lee, 2014). Unfortunately, no one of the teachers was able to provide a successful identification of the levels of the SAMR model or any other model. This result does not go in line with the TESOL technology standards, particularly Standard 1, which states that "Language teachers demonstrate knowledge and skills in basic technological concepts and optional competence, meeting or exceeding TESOL technology standards for language learners in whatever situation they teach" (cited in Brown and Lee, 2014, p.241). This finding also doesn't go in line with the Puentedura's (2009) TPACK model that emphasizes the hierarchy of technological integration by teachers in pedagogical practice as an evaluation model of teachers' ICT adoption. 


\section{$\triangle$ Macrothink}

The lack of teachers' competency of the SAMR model and other models of technology integration leads to the implication that teachers need to gain adequate training and proficiency in learning technology tools and skills of integration, particularly in preparing activities for the classroom (Hilton, 2016).

\section{Finding two: The Extent to Which technology is Integrated into The Classroom Based on the SAMR Model}

In response to Research Question 2: To what extent do teachers integrate technology into their teaching? The results revealed several findings. The first finding indicated that the extent of technology integration is dominated by several factors, such as the type of language course, level of the course, and the needs of students. The excerpt below indicates this view.

\section{Excerpt 1}

Although I don't frequently follow a systematic way or a specific model for monitoring how I integrate technology into my teaching practices, I believe that the process is dominated by certain aspects such as the type of the course, the level of the course, and the student needs. For example, my integration of technology is high in the writing and reading comprehension courses more than other language skills courses... Also, the integration is high with low-level courses because I rely on activities more than lectures.

The second finding indicated that although the teachers try to integrate technology across all the levels of their teaching in terms of Bloom's Taxonomy, they mostly integrate it at a lower level (substitution and augmentation). At the level of substitution, all teachers indicated that they use digital materials instead of printed materials. For example, one of the participants reported that:

\section{Excerpt 2}

I usually use digital materials and texts to present the lecture content. Mostly, I prefer to use PowerPoint slides, Prezi, Youtube videos, Ted Talks, and sometimes TV shows, especially for teaching speaking skills and some times for reading and writing skills.

At the level of augmentation, where "Tech acts as the direct tool of substitution, but with functional changes" (Puentedura, 2009), the third finding revealed that all teachers integrate technology into their practices, particularly when they assign activities and tasks. All teachers reported that recently they have been thinking of digital activities using social media such as Facebook, WhatsApp, Google Doc, Q.R. code activity, Flicker activity, etc. However, the teachers reported that they don't frequently assign these activities as one of them said, "they are time-consuming, and I don't feel they match the formal teaching." This use of mobile technology and social media could be classified as augmentation as it requires 
students to do a functional task through using technology. With regard to the advanced levels of the SAMR model-Modification and Redefinition-the teachers reported that they integrate technology to a limited extent when they assign google doc writing activity and ask students to share their written texts with others. They didn't provide any further examples to confirm their familiarity with the SAMR levels or any other models of technology integration. There is no evidence in the data showing how teachers integrate technology according to the measurement of the SAMR model. Additionally, little is known about the extent to which they integrate technology into the Modification and Redefinition levels.

In light of these findings, we can derive several interpretations. The first interpretation is that the teachers' high frequency of integration at the Substitution and Augmentation levels indicate their focus on preparing digital materials. This is an essential component of the process of course design (Graves, 2000, Richards, 2007; Alkhalidi, 2019). Furthermore, digital materials play a significant role in generating positive effects on students' learning through creating communication, interaction, and motivation in EFL classroom (Richards, 2007; Nunan, 2004; Oxford and Sherain,1944). However, teachers' focus on material design is not sufficient unless it is supported by adopting a dynamic and interactive methodology (Graves, p.x.).

The second set of findings based on the second research question indicated a lack of teachers' interaction with technology tools that are considered as a big challenge from the perspectives of technology integration adherents (Blewet, 2013; Kim et al., 2007, Puentedura, 2009, Chun, 2008). Teachers' lack of interaction with technology tools may lead to negative impacts on the learning-centered methodology that put emphasis on the adaptation of technology in fostering student-centered learning in English as a foreign or second language environment (Chapelle, 2013; Lee and Brown, 2014). Also, Learners of English need to be exposed to various forms of interaction by means of technology for the purpose of communication. For example, they need communication with speakers of the target language through synchronous and asynchronous written online chatting (Chun, 2008) to increase their proficiency.

Furthermore, the teachers' focus on the substitution and augmentation levels of technology integration is considered as a serious challenge to the key principle of integration in classroom teaching. In their focus on increasing opportunities for interaction, Brown and Lee (2014) refer to the role of technology, viewing it as "integral rather than a supplementary" aspect in language learning. This is because technology integration helps increase opportunities for interaction, access to authentic materials, and agency and identity.

\section{Samples of Integrating the SAMR Model in English Language Learning}

Based on theoretical perspectives relating to the SAMR model and Bloom's Taxonomy, this study has further narrowed down to develop a model specifically designed for teaching language courses among undergraduate students that can be utilized by teachers in the TESOL area. Below are three samples picked up from previous studies in the literature on technology integration. The selection of these samples is determined by (1) their direct 
relevance to the TESOL field, and (2) the organization and development of each activity according to the four levels of the SAMR model. The samples will be organized in a format of three tables $(2,3 \& 4)$, as indicated below. In light of these formats, the author is presenting a more holistic and contextual format that is designed in line with the purpose of the study and the field of TESOL. The format in Table 4 can be used as a rubric for developing classroom activities to facilitate learning needs and fulfill the course goals.

Table 2. SAMR Model for Teaching English Literature

\begin{tabular}{|l|l|l|}
\hline Course: & Shakespeare's Macbeth \\
\hline $\begin{array}{l}\text { GAMR } \\
\text { Ladder }\end{array}$ & $\begin{array}{l}\text { Activity: Read, share, post, and create commentary } \\
\text { texts on Macbeth }\end{array}$ \\
\hline Substitution & $\begin{array}{l}\text { "tech acts as a } \\
\text { substitute, with no } \\
\text { functional change" }\end{array}$ & $\begin{array}{l}\text { Create a Noteshare Notebook with links to websites } \\
\text { with the original text of Macbeth, a critical } \\
\text { commentary about the text, information about } \\
\text { Shakespearean stage, and video clips on classical } \\
\text { performances of Macbeth. You can also post } \\
\text { comments and ask questions through blogs }\end{array}$ \\
\hline Augmentation & $\begin{array}{l}\text { "tech acts as a } \\
\text { direct tool } \\
\text { substitute, with } \\
\text { functional } \\
\text { improvement" }\end{array}$ & $\begin{array}{l}\text { add some resources such as 'Flickr Shakespeare } \\
\text { group'. Also refer to the blogs on Shakespeare's work } \\
\text { to learn how his work is being appreciated around the } \\
\text { world. }\end{array}$ \\
\hline $\begin{array}{l}\text { Modification } \\
\text { "tech allows for } \\
\text { significant } \\
\text { redesign" }\end{array}$ & $\begin{array}{l}\text { "tech allows for the } \\
\text { creation of new } \\
\text { tasks, previously } \\
\text { inconceivable" } \\
\text { or 'Many eyes' to visualize the frequent use of words } \\
\text { or phrases in Macbeth. }\end{array}$ & $\begin{array}{l}\text { upload their own performance of Macbeth on the } \\
\text { internet using 'Xtranormal', or 'Second life' }\end{array}$ \\
\hline Redefinition & \\
\hline
\end{tabular}

Table 3. SAMR Model for Teaching English Essay Writing

\begin{tabular}{|l|l|l|}
\hline Course: & Essay Writing \\
\hline $\begin{array}{l}\text { SAMR } \\
\text { Goal } \\
\text { Ladder }\end{array}$ & $\begin{array}{l}\text { Activity: Write an argumentative essay on Woman } \\
\text { Rights. }\end{array}$ \\
\hline Substitution & $\begin{array}{l}\text { "tech acts as a } \\
\text { direct tool } \\
\text { substitute, with no } \\
\text { functional change" }\end{array}$ & $\begin{array}{l}\text { Write a four paragraph argumentative essay on } \\
\text { Woman Rights. Print out your essay using Word.... }\end{array}$ \\
\hline
\end{tabular}




\begin{tabular}{|l|l|l|}
\hline Augmentation & $\begin{array}{l}\text { "tech acts as a } \\
\text { direct tool } \\
\text { substitute, with } \\
\text { functional } \\
\text { improvement" }\end{array}$ & $\begin{array}{l}\text { use a thesaurus or apply google translate to find the } \\
\text { words' synonym or antonym, using check documents } \\
\text { (in the word processing tool) or Grammarly a free } \\
\text { writing assistance software for spelling and } \\
\text { grammatical checkers }\end{array}$ \\
\hline Modification & $\begin{array}{l}\text { "tech allows for } \\
\text { significant } \\
\text { redesign" }\end{array}$ & $\begin{array}{l}\text { Write collaboratively using Google Doc., and then } \\
\text { they give peer feedback online in the Google Doc. } \\
\text { platform. }\end{array}$ \\
\hline Redefinition & $\begin{array}{l}\text { "tech allows for the } \\
\text { creation of new } \\
\text { tasks, previously } \\
\text { inconceivable" }\end{array}$ & $\begin{array}{l}\text { Post your views on the topic "Woman Rights" on the } \\
\text { Facebook. }\end{array}$ \\
\hline
\end{tabular}

Table 4. SAMR Model Based Rubric

\begin{tabular}{|c|c|c|}
\hline \multicolumn{2}{|l|}{ Course: } & \\
\hline \multicolumn{2}{|l|}{$\begin{array}{l}\text { SAMR } \\
\text { Goal } \\
\text { Ladder }\end{array}$} & Activity: \\
\hline Substitution & $\begin{array}{l}\text { "tech acts as a } \\
\text { direct tool } \\
\text { substitute, with no } \\
\text { functional change" }\end{array}$ & \\
\hline Augmentation & $\begin{array}{lr}\text { "tech acts as a } \\
\text { direct } & \text { tool } \\
\text { substitute, } & \text { with } \\
\text { functional } & \\
\text { improvement" } & \end{array}$ & \\
\hline Modification & $\begin{array}{l}\text { "tech allows for } \\
\text { significant } \\
\text { redesign" }\end{array}$ & \\
\hline Redefinition & $\begin{array}{l}\text { "tech allows for the } \\
\text { creation of new } \\
\text { tasks, previously } \\
\text { inconceivable" }\end{array}$ & \\
\hline
\end{tabular}




\section{Conclusion}

Research in technology education, in general, has recently put a great emphasis on examining and addressing the new trend of technology integration into education. A great amount of empirical research has shown the importance of technology in English language learning. However, in certain TESOL contexts, technology is not used at the highest hierarchy according to the measurements of the SAMR model. Thus, this article aims to provide insights on how to integrate technology in the TESOL classroom systematically and properly in a way that lines with the approaches and frameworks of digital pedagogy. For this purpose, the author has reviewed the literature on the SAMR model as one of the most effective models that can be used as a measuring tool of the hierarchy of technology integration in a TESOL classroom.

The research offers certain implications regarding technology integration. Among the implications is that TESOL teachers are encouraged to use the SAMR model as a measuring tool or rubric to follow up their integration of technology across all the stages of a lecture or course design. When teachers become more familiar with the methods and tools of technology integration, they will be able to incorporate technology into higher-level tasks.

Based on theoretical views and the analysis of teachers' perspectives in this case study, the research presents a model that is in line with the SAMR model. More importantly, the model is shaped and guided by the principles of a learner-centered approach. The model is considered as an opportunity for teachers to practice the application of technology tools and skills in their teaching practices independently.

\section{Limitation of the Study}

The present study is a small scale case study that is conducted within a bound context with a small group of participants. This may have an impact on the criterion of generalizability. The limitation of this study may be that detailed background information on teachers' challenges and the factors affecting their use and integration of technology is not provided. Our understanding could be enriched if more participants are involved in this study.

\section{Acknowledgments}

I sincerely thank the teachers who participated in this study and provided me with rich insight data through reflective reports.

\section{References}

Abdullah, M. R. T. L. (2014). Development of activity-based mLearning implementation model for undergraduate English language learning. Doctoral dissertation, University of Malaya. 
Alkhalidi, I. (2020). Investigating the process of EAP course design from the perspectives of teachers. British Journal of English Linguistics, 8(4), 1-26.

Aliva, J.S. (2019). A review of TPACK and SAMR models: How should language teachers adopt technology. Journal of English for Academic and Specific Purposes, 2(2), 1-11.

Andrew Churches (2008). Bloom's Digital Taxonomy. https://www.academia.edu.

Barton, R., \& Hayden, T. (2006). Trainee teachers' views on what helps them to use information and communication technology effectively in their subject teaching. Journal of Computer assisted Learning, 22(4), 257-272.

Blewett, C., Quilling, R., Bulbulia, Z., \& Wamuyu, R.K. (2011). Student challenges in a virtual collaborative learning course spanning multiple countries. Alternation, 18(2), 1023-1757.

Brown, H.D., \& Lee, H. (2014). Teaching by principles: An interactive approach to language pedagogy. New York: Pearson Education, Inc.

Budiman, A., Rahmawati, R., \& Amalia, Ulfa, R.A. (2018). EFL teacher's belief and practice on integrating ICT in the classroom: A case study of implementation of SAMR model in teaching reading descriptive texts at Ma Assalam, Sukoharjo. Journal Penelitian Humaniora, 19(2), 39-51.

Canagarajah, S. (2005). Critical pedagogy in L2 learning and teaching. In E. Hinkel (Ed.), Handbook of research in second language teaching and learning (pp. 931-949). Mahwah, NJ: Lawrence Erlbaum Associates.

Chapelle, C. (2013). Instructional computer-assisted language learning. In C. Chapelle (Ed.), The encyclopedia of applied linguistics (pp.2718-2721). West Sussex, UK. Wily-Blackwell.

Chapelle, C., \& Duff, P. (2003). Some Guidelines for Conducting Quantitative and Qualitative Research in TESOL QUARTERLY, 37(1), 157-177.

Cassim, K.M., \& Obono, S.E. (2011). On the factors affecting the adoption of ICT for the teaching of word problems. In Proceedings of the World Congress on Engineering and Computer Science, 1, pp. 19- 21).

Chou, C.C., Block, L., \& Jesness, R. (2012). A case study of mobile learning pilot project in K-12 schools. Journal of Educational Technology Development and Exchange, 5(2), 11-26.

Chun, D. (2008). Computer-mediated discourse in instructed environments. In S. Magnan (Ed.), Mediating discourse online (pp. 15-44). Amsterdam, The Netherlands: John Benjamins.

Devers, K., \& Frankel, R. (2000). Study Design in qualitative Research- 2: Sampling and Data Collection Strategies. Education for Health, 13(2), 263-271.

Donna Marie Ledford, D.M. (2016). Development of learning framework to improve teacher practice in technology integration. Boise State University. Unpublished Dissertation. 
Dornyei, Z. (2011). Research methods in applied linguistics. Oxford: Oxford University Press.

Esterberg, K.G. (2002). Qualitative Methods in Social Research. McGraw-Hill Companies.

Fabian, K., \& MacLean, D. (2014). "Keep taking tablets? Assessing the use of tablet devices in learning and teaching activities in the Further Education sector", Research in Learning Technology, Vol 22, No. 22648. http://dx.doi.org/10.3402/rlt.v22.22648

Graves, K. (2000). Designing language courses: A guide for teachers. Boston: M.A. Heinle \& Heinle.

Jamieson-Proctor, R., Finger, G., Cavanagh, R., Albion, P., Fitzgerald, R., Bond, T., \& Grimbeek, P. (2013). Development of the TPACK Survey. Australian Educational Computing, Special Edition: Teaching Teachers for the Future Project. Vol 27.3 (2013), 26-35.

Howlett, K.M., Mysore, A.R., Christ, \& Beck, D. (2019). An English Learner Servicelearning Project: Preparing Education Majors Using Technology and the SAMR Model. CALL-EJ, 20(2), 128-149.

Hilton, A. (2016). Incorporating Digital technologies into Science classes: Two case studies from the field. International Journal of Pedagogies and Learning, 8(3), 153-186.

Hughes, J.E., Thomas, R., \& Scharber, C. (2006). Assessing technology integration: The RAT Replacement, Amplification, and Transformation - Framework. Paper presented at the Society for Information Technology and Teacher Education, Orlando.

Huang, K. H., Hung, K. C., \& Cheng, C. C. (2012). Enhancing interactivity in geography class: Fostering critical thinking skills through technology. Problems of Education in the 21st Century, 50 .

Kim, C., Kim M. K., Lee, C., Spector, J. M., \& DeMeester, K. (2013). Teacher beliefs and technology integration. Teaching and Teacher Education, 29, 76-85.

Koehler, M.J., Mishra, P., \& Yahya, K. (2007). Tracing the development of teacher knowledge in a design seminar: Integrating content, pedagogy, and technology. Computers in Education, 49, 740-762.

Koehler, M.J., \& Mishra, P. (2009). What is technological pedagogical content knowledge? Contemporary Issues in Technology and Teacher Education, 9(1), 60-70.

Kolb, L. (2017). Learning first, technology second: An educator's guide to designing Authentic lessons. Portland: International Society for Technology in Education.

Lawless, K.A., \& Pellegrino, J.W. (2007). Professional development in integrating technology into teaching and learning: Knowns, unknowns, and ways to pursue better questions and answers. Review of Educational Research, 77(4), 575-614.

Ledford, D.M. (2016). Development of professional learning framework to improve teacher 
practice in technology integration. Unpublished Dissertation. Boise State University.

Littlewood, W. (2011). Communicative language teaching: An introduction. Cambridge, UK: Cambridge University Press.

Matherson, L. H., Wilson, E. K., \& Wright, V. H. (2014). Need TPACK? Embrace sustained professional development. The Delta Kappa Gamma Bulletin, 81(1), 45-52.

Miles, M. B., \& Huberman, A. M. (1994). Qualitative data analysis: An expanded sourcebook. Thousand Oaks, CA: Sage.

Mouza, C., \& Karchmer-Klein, R. (2013). Promoting and assessing pre-service teachers technological pedagogical content knowledge in the context of case development. Journal of Educational Computing Research, 48(2), 127-152. https://doi.org/10.2190/EC.48.2.b

Nakayima, J.K. (2011). Perceived usefulness, perceived ease of use, behavioural intention to use and actual system usage in Centenary Bank (Doctoral dissertation, Makerere University).

Nakapan, W. (2016). Using the SAMR model to transform learning in a history of art and architecture classroom. Living Systems and Micro- Utopias: Towards Continuous

Designing, Proceedings of the 21st International Conference of the Association for Computer-Aided Architectural Design Research in Asia CAADRIA 2016, 809-818.

Nunan, D. (2004). Task-Based language Teaching. Cambridge: Cambridge University Press.

Oxford, R., \& Sherain, J. (1944). Language Learning Motivation: Expanding Theoretical Framework. The Modern Language Journal, 78(1), 12-28.

Park, J. (2014). Running head: PLN technology integration the use of professional learning networks and technology integration. PLN Technology Integration, 1-22.

Puentedura, R. (2009). As We May Teach: Educational Technology, From Theory into Practice.

Puentedura, R. (2012). Technology in Education: The First 200,000 years. The NMC Perspective Series: Ideas that Matter, NMC Summer Conference.

Pfaffe, L. D. (2017). Using the SAMR model as a framework for evaluating mLearning activities and supporting a transformation of learning (Unpublished doctoral dissertation). St. John's University, New York.

Prensky, M., (2005). Adopt and adapt: Shaping tech for the classroom. The George Lucas Educational Foundation Reprint Policy: http://www.edutopia.org/reprintpolicies

Richards, J.C. (2007). Curriculum Development in Language Teaching. Cambridge: Cambridge University Press.

Saran, M. \& Seferoglu, g. (2012). Mobile language Learning: Contribution of Multimedia messages via mobile Phones in consolidating vocabulary. The Asia Pacific Education Researcher, 21(1), 18. 
Shu-Yuan Fan, V. (2016). Strategies for Integrating Digital Technology in Classrooms to support English Language Learners' Learning and Engagements, Digital Technology Integration to support ELLs' learning and engagements.

Strauss, A., \& Corbin, J. (1998). Basics of qualitative research: Techniques and procedures for developing grounded theory (2nd ed.). Sage Publications, Inc.

Tondeur, J. Scherer, R.; Baran, E., Siddiq, F., Valtonen, T., Sointu, E. (2019). Teacher educators as gatekeepers: Preparing the next generation of teachers for technology integration in education. British Journal of Educational Technology, Vol, 50, No. 3, p 1189-1209.

Wang, H. (2006). An implementation study of the English as a foreign language curriculum policies in the Chinese tertiary context. Unpublished doctoral thesis, Queen's University, Kingston, Ontario, Canada.

Wang, S., \& Smith, S. (2013) Reading and grammar learning through mobile phones. language learning \& technology, 17(3), 117-134.

Yang, S., \& Walker, V. (2016). A pedagogical framework for technology integration in ESL classroom: The promises and challenges of integration. Journal of Applicational Multimedia and Hypermedia, 24(2), 179-203.

Yin, R.K. (2009). Case study research: Design and methods (4th ed.). Thous and Oaks, CA: Sage.

\section{Copyright Disclaimer}

Copyright for this article is retained by the author(s), with first publication rights granted to the journal.

This is an open-access article distributed under the terms and conditions of the Creative Commons Attribution license (http://creativecommons.org/licenses/by/3.0/). 